\title{
CHEMICAL STABILIZATION OF FATS RICH IN LONG CHAIN POLYUNSATURATED FATTY ACIDS BY ANTIOXIDANTS ADDITION
}

\author{
FLAVIA POP ${ }^{a, *}$, DANIEL NĂSUI ${ }^{a}, Z^{2}$ RICA VOȘGAN ${ }^{a}$, \\ CRISTINA MIHALIa ${ }^{\text {, CLAUDIA BUTEAN }}{ }^{\mathrm{a}}$
}

\begin{abstract}
The research was conducted in order to evaluate the effect of natural ( $\beta$-carotene and ascorbic acid) antioxidants on the oxidative stability of alimentary chicken fat in order to improve its safety and extend the shelf life. Peroxide value was significantly influenced by the storage time $(p<0.001)$ in chicken fat and $0.01 \%$ additivated fat. In control was found the highest level of peroxide value followed by $0.01 \%$ and $0.05 \%$ additivated fat. Regardless of the type of fat, the highest peroxide index level was found at 180 days of storage. Saturated fatty acids content increased, but monounsaturated and polyunsaturated fatty acids content decreased during refrigerated storage. Storage time showed to be most correlated with monounsaturated fatty acids for control $(r=0.93)$, followed by $0.01 \%$ additivated fat $(r=0.87)$ and $0.05 \%$ additivated fat $(r=0.76)$. The development of rancidity in chicken fat was significantly $(p<0.01)$ reduced by the addition of $\beta$-carotene and ascorbic acid in concentration of $0.05 \%$.
\end{abstract}

Keywords: chemical stabilization, $\beta$-caroten, ascorbic acid, peroxide index, fatty acid profile

\section{INTRODUCTION}

Storage of food products rich in polyunsaturated fatty acids even in refrigerated and frozen conditions affects in time the organoleptic, physicochemical and nutritional properties following oxidative or lipolytic

\footnotetext{
a Technical University of Cluj-Napoca, North University Center of Baia Mare, Chemistry and Biology Department, 76A Victoriei Str., 430122, Baia Mare, Romania

*Corresponding author e-mail: flavia_maries@yahoo.co
} 
rancidity and may result in reduction of their shelf life. Lipid oxidation products affect food quality due to changes in color, flavor, texture and nutritional value [1]. A high oxidative stability of lipids is very important for human health and for economic reasons. Antioxidants can be used to inhibit or retard the effects of oxidative rancidity. Synthetic antioxidants are the most used, but their safety has been questioned due to potential toxicological concerns. The natural antioxidants have gained increased interest because of the belief that natural food ingredients are better and safter than synthetic ones [2,3].

$\beta$-Carotene is an organic, red-orange pigment abundant in plants and fruits. It is a member of the carotenes, which are terpenoids (isoprenoids), synthesized biochemically from eight isoprene units and having 40 carbons (Fig. 1). Among the carotenes, $\beta$-carotene is distinguished by having betarings at both ends of the molecule. When used as a food coloring, it has the E number E160a. In nature, $\beta$-carotene is a precursor to vitamin A via the action of beta-carotene 15,15'-monooxygenase $[4,5]$.

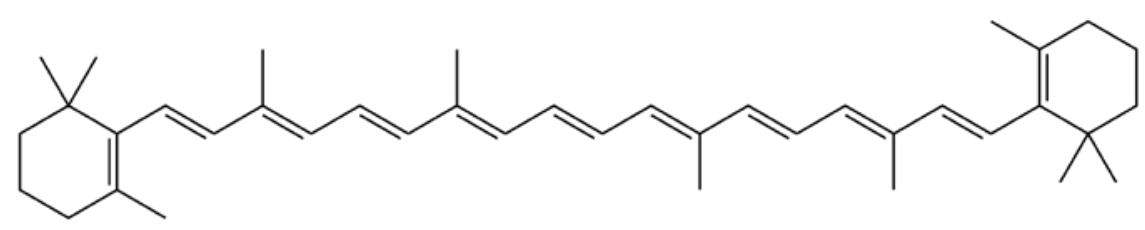

Figure 1. The chemical structure of $\beta$-carotene[4]

Ascorbic acid (AA), commonly known as vitamin $C$, plays an important role in the human body, although its function at the cellular level is not yet clear. It is necessary for the synthesis of collagen, a protein that has many connective functions in the body [6]. Ascorbic acid is the enolic form of one $\alpha$-ketolactone. Ascorbic acid solution is easily oxidized to the diketo form referred to as dehydroascorbic acid, which can easily be converted into oxalic acid, diketogulonic acid or threonic acid. It contains several structural elements that contribute to its chemical behavior: the structure of lactones, two enolic hydroxyl groups and a primary and secondary alcohol group. Enediol structure motivates the antioxidant properties, as can easily oxidized enediols to diketones [7-10].

Ascorbic acid is considered an antioxidant because it can supply an electron to a species with an unpaired electron to stabilize the radical (Fig. 2). Because radicals normally poach electrons from surrounding molecules to pair with their lone electron, they normally cause a chain reaction where 
their victim goes on to pull electrons from another neighboring molecule (oxidation), and so on and so forth. However, because the ascorbyl radical is stable, it is less likely to poach an electron from another molecule in its environment, preventing the chain reaction from occurring $[11,12]$.

The objective of the study consisted in analysis the effect of natural $(\beta$-carotene and ascorbic acid) antioxidants at two concentrations ( 0.01 and $0.05 \%)$ on the oxidative stability of alimentary chicken fat in order to improve its safety and extend the shelf life.
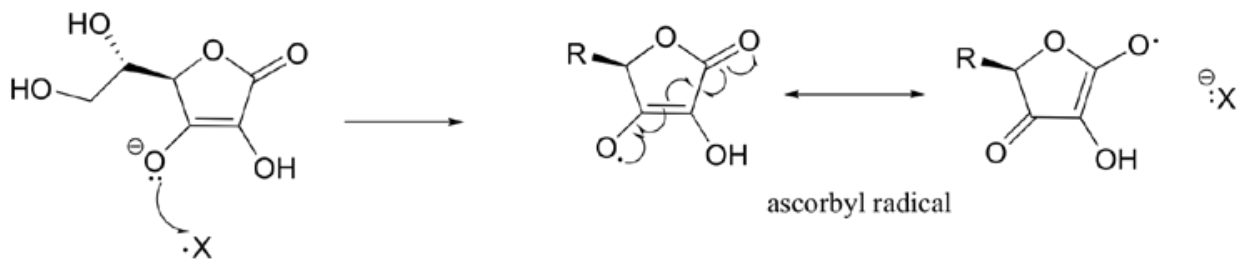

Figure 2. The antioxidant mechanism of ascorbic acid [11]

\section{RESULTS AND DISCUSSION}

Acid value, peroxide value, refractive index value, iodine value and fatty acids profile were determined in order to asses the effect of antioxidants addition on chicken fat stability in order to improve its shelf life during refrigerated storage.

Acid value represents an analytical parameter which is used to evaluate the hydrolysis extension in fats during storage. An increase in this parameter indicates a higher presence of free fatty acids, a direct consequence of hydrolysis, and it is an important indicator of fat chemical deterioration [13].

The results of chemical analysis for chicken fat and additivated fat are tabulated in Tables 1-3, respectively. In chicken fat (control) was found the highest level of acid value followed by $0.01 \%$ ascorbic acid, $0.01 \% \beta$ carotene, $0.05 \%$ ascorbic acid and $0.05 \% \quad \beta$-carotene additivated fat. Regardless of the type of fat, the highest acid value was found at 180 days of storage. Acid value increased from 0.18 to $1.24 \mathrm{~g}$ oleic acid/100 g in control; to $1.16 \mathrm{~g}$ oleic acid $/ 100 \mathrm{~g}$ in $0.01 \% \beta$-carotene additivated fat; to $1.21 \mathrm{~g}$ oleic acid $/ 100 \mathrm{~g}$ in $0.01 \%$ ascorbic acid additivated fat; to $1.08 \mathrm{~g}$ oleic acid $/ 100 \mathrm{~g}$ in $0.05 \% \beta$-carotene additivated fat and to $1.11 \mathrm{~g}$ oleic acid $/ 100 \mathrm{~g}$ in $0.05 \%$ ascorbic acid additivated fat stored at $2-4^{\circ} \mathrm{C}$. Acid values exceeded the limit ( $\leq 1 \mathrm{~g}$ oleic acid/ $100 \mathrm{~g}$ fat) after 120 days of 
storage in chicken fat, 150 days in $0.01 \% \beta$-carotene and $0.01 \%$ ascorbic acid additivated fat, and 180 days in $0.05 \% \beta$-carotene and $0.05 \%$ ascorbic acid additivated fat.

Pereira et al., reported that the formation of free fatty acids was significantly lower in cod liver oil with natural antioxidant from barley husks than in the control samples [14].

Peroxide value is a measure of primary lipid oxidation, indicating the amount of peroxides formed during oxidation. The products of lipid oxidation such as peroxides, free radicals, malonaldehyde and other cholesterol oxidation products are reported to promote coronary heart disease and atherosclerosis [15].

Peroxide value was significantly influenced by the storage time $(p<$ 0.001 ) in chicken fat and $0.01 \%$ additivated fat. In control was found the highest level of peroxide value followed by $0.01 \%$ and $0.05 \%$ additivated fat. Regardless of the type of fat, the highest peroxide index level was found at 180 days of storage. Peroxide index values increased from 2.18 to 15.28 meq $\mathrm{O}_{2} / \mathrm{kg}$ in control; to 12.77 meq $\mathrm{O}_{2} / \mathrm{kg}$ in $0.01 \% \beta$-carotene additivated fat and to $11.16 \mathrm{meq} \mathrm{O}_{2} / \mathrm{kg}$ in $0.05 \% \beta$-carotene additivated after 180 days of refrigerated storage. Peroxide index values at the end of refrigerated storage were $14.17 \mathrm{meq} \mathrm{O}_{2} / \mathrm{kg}$ in $0.01 \%$ ascorbic acid additivated fat and $11.39 \mathrm{meq}$ $\mathrm{O}_{2} / \mathrm{kg}$ in $0.05 \%$ ascorbic acid additivated fat. Peroxide value exceeded the limit $\left(10 \mathrm{meq} \mathrm{O}_{2} / \mathrm{kg}\right)$ after 90 days of storage in control, 120 days in $0.01 \% \beta$ carotene and $0.01 \%$ ascorbic acid additivated fat, and 150 days in $0.05 \% \beta$ carotene and $0.05 \%$ ascorbic acid additivated fat.

Table 1. Changes in quality parameters of chicken fat during refrigerated storage

\begin{tabular}{|l|c|c|c|c|}
\hline Storage time & \multicolumn{4}{|c|}{ Chicken fat (control) } \\
\cline { 2 - 5 } & $\begin{array}{c}\mathrm{PV} \\
\text { (meq O/kg fat) }\end{array}$ & $\begin{array}{c}\mathrm{AV} \\
\text { (g oleic } \\
\text { acid/100 g fat) }\end{array}$ & $\begin{array}{c}\mathrm{RIV} \\
\text { (refractometric } \\
\text { degrees) }\end{array}$ & $\begin{array}{c}\mathrm{IV} \\
(\mathrm{g} \mathrm{I} / 100 \mathrm{~g} \text { fat) }\end{array}$ \\
\hline 1 day & $2.18^{\mathrm{ij}}$ & $0.18^{\mathrm{h}}$ & $1.4648^{\mathrm{a}}$ & $89.7^{\mathrm{a}}$ \\
\hline 30 days & $3.57^{\mathrm{hi}}$ & $0.35^{\mathrm{g}}$ & $1.4637^{\mathrm{a}}$ & $88.4^{\mathrm{b}}$ \\
\hline 60 days & $6.83^{\mathrm{g}}$ & $0.58^{\mathrm{f}}$ & $1.4625^{\mathrm{ab}}$ & $86.9^{\mathrm{b}}$ \\
\hline 90 days & $9.14^{\mathrm{de}}$ & $0.83^{\mathrm{cd}}$ & $1.4605^{\mathrm{bc}}$ & $84.1^{\mathrm{bc}}$ \\
\hline 120 days & $11.41^{\mathrm{c}}$ & $0.96^{\mathrm{b}}$ & $1.4583^{\mathrm{c}}$ & $82.2^{\mathrm{c}}$ \\
\hline 150 days & $13.89^{\mathrm{b}}$ & $1.18^{\mathrm{ab}}$ & $1.4562^{\mathrm{d}}$ & $80.1^{\mathrm{d}}$ \\
\hline 180 days & $15.28^{\mathrm{a}}$ & $1.24^{\mathrm{a}}$ & $1.4539^{\mathrm{de}}$ & $77.4^{\mathrm{e}}$ \\
\hline$p$ & $<0.001^{\star \star \star}$ & $<0.001^{\star \star \star}$ & $<0.01^{\star \star}$ & $<0.01^{\text {}}$ \\
\hline
\end{tabular}

a) PV, peroxide value; AV, acid value; RIV, refractive index value; IV, iodine value.

b) Values are expressed as mean.

c) Different letters in the same column indicate statistically significant differences (Tukey's test $p<0.05$ ).

d) Significant differences are denoted by asterisks: ${ }^{\star} p<0.05$; ${ }^{\star \star} p<0.01$; ${ }^{\star \star \star} p<0.001 ; p \geq 0.05$, non-significant. 
The results of several research confirm the efficacy of a natural and synthetic antioxidants to slow down the progress of lipid hydrolysis and increase oxidative stability in fatty foods [16-19]. Pereira et al. reported that the natural antioxidant derived from barley husks has a better antioxidant activity in cod liver oil than $t$-butyl-4-hydroxyanisole (BHA) or 2,6-di-t-butyl$p$-hydroxytoluene (BHT) in reducing the production of primary and delaying secondary oxidation products [14].

The effects of natural ( $\alpha$-tocopherol) and synthetic (BHA and BHT) antioxidants on the oxidative stability of butter were investigated by Ozturk and Cakmakci [20]. The researchers found that butter samples treated with 50 and $100 \mathrm{ppm}$ of the antioxidants provided significantly lower peroxide index values compared to the control group. The study showed that butter samples with $50 \mathrm{ppm} \alpha$-tocopherol could be stored for more than 180 days at $4^{\circ} \mathrm{C}$ without spoilage. Zuta et al. studied the effect of 50,100, 250 and $500 \mathrm{ppm}$ concentrations of $\alpha$-tocopherol on the oxidation of unrefined mackerel oil, and reported that low concentrations of $\alpha$-tocopherol minimized autooxidation of unrefined mackerel oil, while higher concentrations of $\alpha$ tocopherol were less effective as antioxidant [21].

Table 2. Changes in quality parameters of $\beta$-carotene additivated fat during refrigerated storage

\begin{tabular}{|c|c|c|c|c|c|c|c|c|}
\hline \multirow{2}{*}{$\begin{array}{c}\text { Storage } \\
\text { time }\end{array}$} & \multicolumn{9}{|c|}{$\mathbf{0 . 0 1 \%} \boldsymbol{\beta}$-Carotene additivated fat } & \multicolumn{5}{|c|}{$\mathbf{0 . 0 5 \%} \boldsymbol{\beta}$-Carotene additivated fat } \\
\cline { 2 - 9 } & $\mathrm{PV}$ & $\mathrm{AV}$ & $\mathrm{RIV}$ & $\mathrm{IV}$ & $\mathrm{PV}$ & $\mathrm{AV}$ & $\mathrm{RIV}$ & $\mathrm{IV}$ \\
\hline 1 day & $2.17^{\mathrm{gh}}$ & $0.17^{\mathrm{fg}}$ & $1.4647^{\mathrm{a}}$ & $89.6^{\mathrm{a}}$ & $2.15^{\mathrm{f}}$ & $0.16^{\mathrm{e}}$ & $1.4648^{\mathrm{a}}$ & $89.5^{\mathrm{a}}$ \\
\hline 30 days & $2.83^{\mathrm{ef}}$ & $0.28^{\mathrm{e}}$ & $1.4639^{\mathrm{a}}$ & $88.9^{\mathrm{a}}$ & $2.51^{\mathrm{de}}$ & $0.21^{\mathrm{d}}$ & $1.4641^{\mathrm{a}}$ & $89.1^{\mathrm{a}}$ \\
\hline 60 days & $5.74^{\mathrm{d}}$ & $0.47^{\mathrm{d}}$ & $1.4628^{\mathrm{ab}}$ & $87.5^{\mathrm{b}}$ & $5.03^{\mathrm{cd}}$ & $0.39^{\mathrm{cd}}$ & $1.4635^{\mathrm{a}}$ & $88.4^{\mathrm{ab}}$ \\
\hline 90 days & $7.82^{\mathrm{cd}}$ & $0.79^{\mathrm{c}}$ & $1.4611^{\mathrm{b}}$ & $84.9^{\mathrm{bc}}$ & $6.82^{\mathrm{c}}$ & $0.67^{\mathrm{c}}$ & $1.4616^{\mathrm{b}}$ & $86.7^{\mathrm{b}}$ \\
\hline 120 days & $9.14^{\mathrm{c}}$ & $0.91^{\mathrm{b}}$ & $1.4589^{\mathrm{bc}}$ & $82.9^{\mathrm{c}}$ & $8.65^{\mathrm{b}}$ & $0.85^{\mathrm{bc}}$ & $1.4594^{\mathrm{bc}}$ & $83.8^{\mathrm{bc}}$ \\
\hline 150 days & $11.31^{\mathrm{b}}$ & $1.02^{\mathrm{ab}}$ & $1.4571^{\mathrm{cd}}$ & $81.1^{\mathrm{cd}}$ & $9.36^{\mathrm{ab}}$ & $0.92^{\mathrm{ab}}$ & $1.4581^{\mathrm{c}}$ & $82.1^{\mathrm{c}}$ \\
\hline 180 days & $12.77^{\mathrm{a}}$ & $1.16^{\mathrm{a}}$ & $1.4548^{\mathrm{d}}$ & $78.8^{\mathrm{e}}$ & $11.16^{\mathrm{a}}$ & $1.08^{\mathrm{a}}$ & $1.4559^{\mathrm{cd}}$ & $80.4^{\mathrm{d}}$ \\
\hline$p$ & $<0.001$ & $<0.001$ & $<0.01$ & $<0.01$ & $<0.01$ & $<0.01$ & $<0.01$ & $<0.01$ \\
\hline
\end{tabular}

\footnotetext{
a) $\mathrm{PV}$, peroxide value (meq $\mathrm{O}_{2} / \mathrm{kg}$ ); $\mathrm{AV}$, acid value (g oleic acid/100 g); RIV, refractive index value (refractometric degrees); IV, iodine value $\left(\mathrm{g} \mathrm{I}_{2} / 100 \mathrm{~g}\right)$.

b) Values are expressed as mean.

c) Different letters in the same column indicate statistically significant differences (Tukey's test $p<0.05$ ).

d) Significant differences are denoted by asterisks: ${ }^{\star} p<0.05$; ${ }^{\star \star} p<0.01 ;{ }^{* \star} p<0.001 ; p \geq 0.05$, nonsignificant.
} 
Table 3. Changes in quality parameters of ascorbic acid additivated fat during refrigerated storage

\begin{tabular}{|c|c|c|c|c|c|c|c|c|}
\hline \multirow[t]{2}{*}{$\begin{array}{l}\text { Storage } \\
\text { time }\end{array}$} & \multicolumn{4}{|c|}{$\begin{array}{l}0.01 \% \text { Ascorbic acid additivated } \\
\text { fat }\end{array}$} & \multicolumn{4}{|c|}{$\begin{array}{l}0.05 \% \text { Ascorbic acid additivated } \\
\text { fat }\end{array}$} \\
\hline & $\mathrm{PV}$ & AV & RIV & IV & $\mathrm{PV}$ & $\mathrm{AV}$ & RIV & IV \\
\hline 1 day & $2.16^{\mathrm{h}}$ & $0.16^{f}$ & $1.4647^{a}$ & $89.6^{a}$ & $2.14^{\mathrm{ef}}$ & $0.15^{e}$ & $1.4648^{a}$ & $89.4^{a}$ \\
\hline 30 days & $2.77^{\mathrm{g}}$ & $0.31^{e}$ & $1.4638^{a}$ & $88.5^{a b}$ & $2.57^{\mathrm{de}}$ & $0.23^{d}$ & $1.4643^{a}$ & $89.1^{a}$ \\
\hline 60 days & $5.93^{\text {ef }}$ & $0.45^{\mathrm{cd}}$ & $1.4631^{\mathrm{ab}}$ & $87.7^{b}$ & $5.16^{\mathrm{cd}}$ & $0.41^{\mathrm{cd}}$ & $1.4633^{a}$ & $88.2^{a b}$ \\
\hline 90 days & $8.11^{d}$ & $0.85^{b c}$ & $1.4609^{b}$ & $85.1^{b c}$ & $7.66^{\mathrm{bc}}$ & $0.72^{c}$ & $1.4618^{b}$ & $86.1^{b}$ \\
\hline 120 days & $9.67^{c}$ & $0.94^{b}$ & $1.4587^{\mathrm{bc}}$ & $82.5^{c d}$ & $8.51^{b}$ & $0.88^{b c}$ & $1.4591^{b c}$ & $83.7^{b c}$ \\
\hline 150 days & $12.03^{b}$ & $1.09^{a b}$ & $1.4569^{\mathrm{cd}}$ & $80.8^{d}$ & $9.88^{a b}$ & $0.96^{\mathrm{ab}}$ & $1.4576^{c}$ & $81.9^{c}$ \\
\hline 180 days & $14.17^{a}$ & $1.21^{\mathrm{a}}$ & $1.4544^{\mathrm{d}}$ & $78.3^{\mathrm{e}}$ & $11.39^{a}$ & $1.11^{\mathrm{a}}$ & $1.4555^{\mathrm{cd}}$ & $79.8^{d}$ \\
\hline$p$ & $<0.001$ & $<0.001$ & $<0.01$ & $<0.01$ & $<0.01$ & $<0.01$ & $<0.01$ & $<0.01$ \\
\hline
\end{tabular}

${ }^{\text {a) }} \mathrm{PV}$, peroxide value (meq $\mathrm{O}_{2} / \mathrm{kg}$ ); $\mathrm{AV}$, acid value (g oleic acid/100 g); RIV, refractive index value (refractometric degrees); IV, iodine value $\left(\mathrm{g} \mathrm{I}_{2} / 100 \mathrm{~g}\right)$.

b) Values are expressed as mean.

c) Different letters in the same column indicate statistically significant differences (Tukey's test $p<0.05$ ).

d) Significant differences are denoted by asterisks: ${ }^{\star} p<0.05$; ${ }^{\star \star} p<0.01$; ${ }^{\star \star \star} p<0.001 ; p \geq 0.05$, nonsignificant.

Refractive index value and iodine value are measures of the degree of unsaturation of fatty acids. Refractive index value declines linearly with iodine value. Refractive index value and iodine value were significantly influenced $(p<0.01)$ by the storage time in all treatments. Positive correlations between refractive index value and iodine value were found in control $(r=0.83 ; p<0.01), 0.01 \% \beta$-carotene additivated fat $(r=0.79 ; p<$ $0.01)$, and $0.01 \%$ ascorbic acid additivated fat $(r=0.85 ; p<0.01)$. Regardless of the type of fat, the lowest iodine index level was found at 180 days of storage. The decrease of refractive index and iodine index levels at storage indicates a reduction of the unsaturation degree of fatty acids, by the split of unsaturated fatty acids double bonds.

Fatty acids represent the main constitutes of the saponifiable fraction of fats, the fatty acids profile at the beginning and at the end of refrigerated storage is reported. The total lipids of the fat samples showed a predominance of monounsaturated fatty acids (MUFA) and polyunsaturated fatty acids (PUFA).

The fatty acids profile of chicken fat was rich in olei (C18:1), vaccenic $\left(C 18: 1_{i}\right)$, eicosenoic (C20:1), linoleic (C18:2), linolenic (C18:3) and arachidonic (C20:4) fatty acids, followed by palmitic (C16:0), stearic (C18:0) and miristic (C17:0) acids (Fig. 3). 


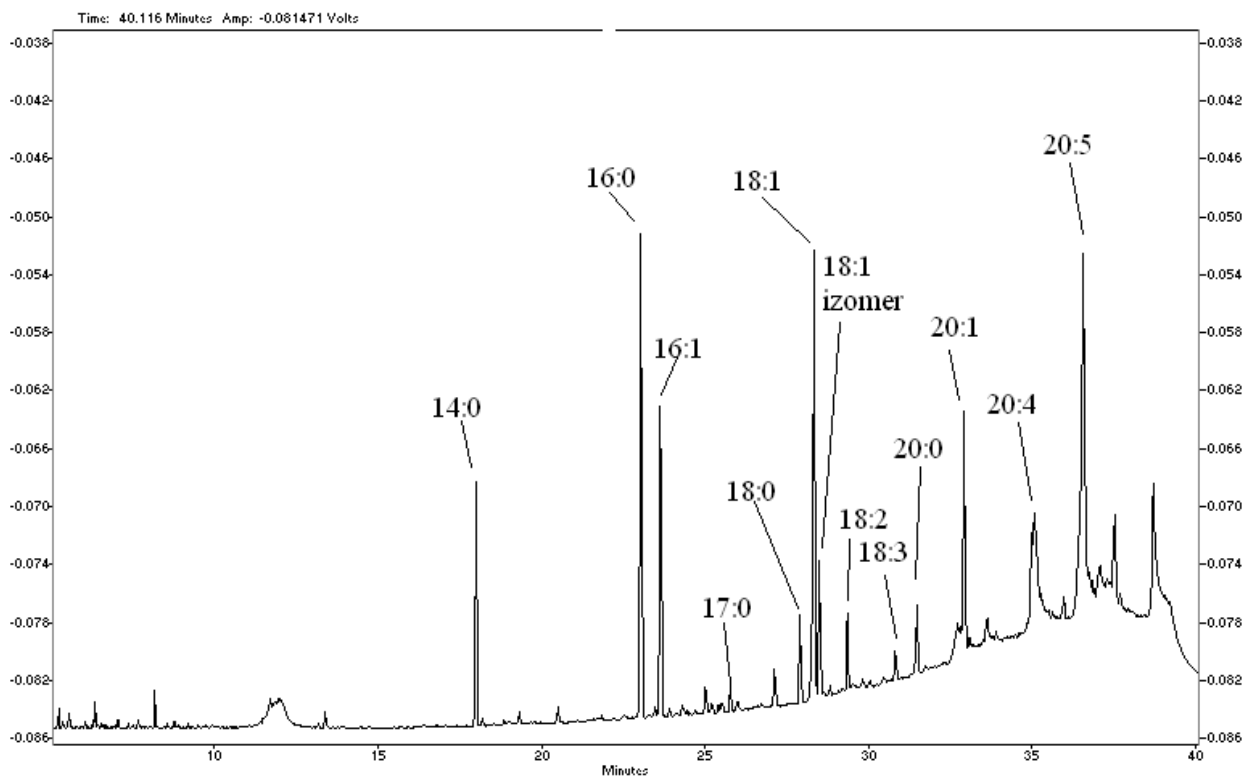

Figure 3. Gas chromatogram of fresh chicken fat

Saturated fatty acids (SFA) content increased, but monounsaturated and polyunsaturated fatty acids content decreased during refrigerated storage. Storage time showed to be most correlated with MUFA for control $(r=0.93)$, followed by $0.01 \%$ additivated fat $(r=0.87)$ and $0.05 \%$ additivated fat $(r=0.76)$.

Storage time inflicted changes in fatty acids profile of chicken fat. Analyzing the fatty acids by their common nature, the most affected fraction was the polyunsaturated fatty acids (PUFA), directly related with their higher number of double bonds, with higher susceptibility to oxidation (Fig. 4, Fig. 5). At 180 days of refrigerated storage, PUFA content decreased around $13 \%$ in control and around $9 \%$ in $0.05 \%$ additivated fat. Taking into account that in chicken fat was found the highest level of peroxide value, the decrease of total PUFA during storage may be due to the oxidation of polyunsaturated fatty acids.

Jankowski et al. determined the effect of diets with a different $n-6 / n$ 3 PUFA ratio (7.31, 4.43 and 0.99$)$ and antioxidants on the fatty acid profile, oxidative status and sensory properties of turkey fat. The researchers showed that fat of turkeys fed with linseed oil enriched with $\alpha$-tocopherol, ascorbic acid and selenium was characterized by higher concentrations of 
total PUFA, a significantly lower $n-6 / n-3$ PUFA ratio, a higher thiobarbituric acid reactive substances content, and after 4 months of deep-freeze storage the $n-6 / n-3$ PUFA ratio did not deteriorate [22].

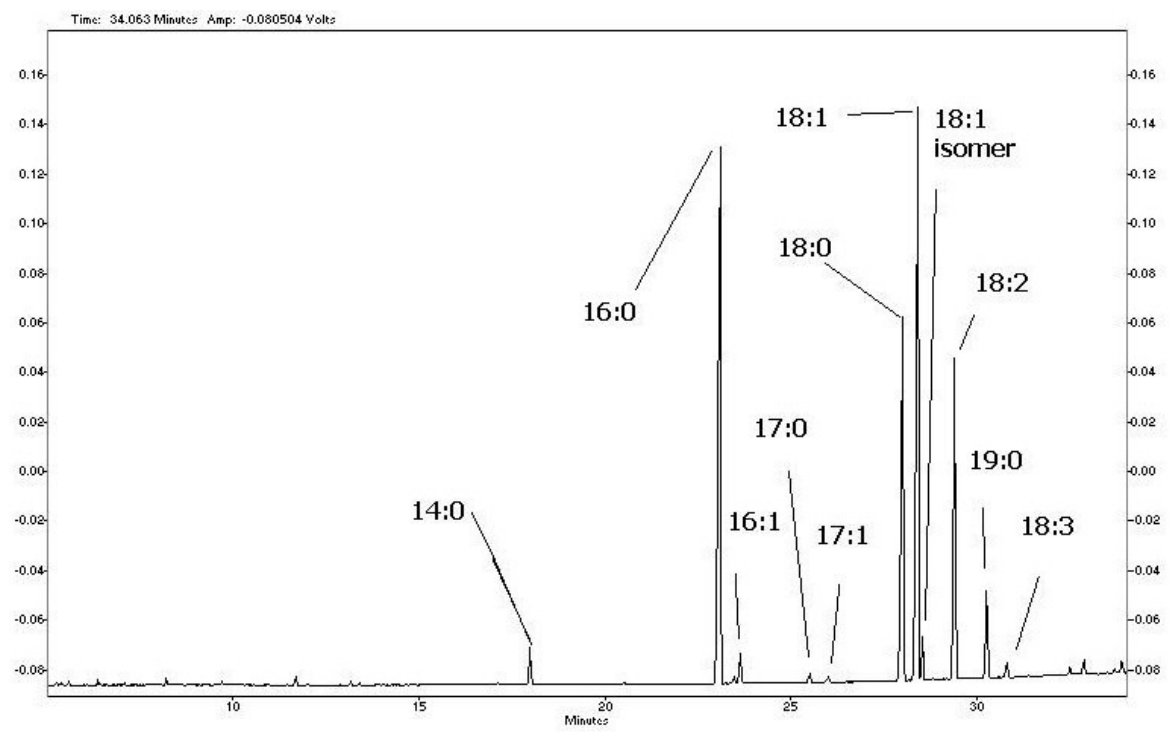

Figure 4. Gas chromatogram of chicken fat at 180 days of storage

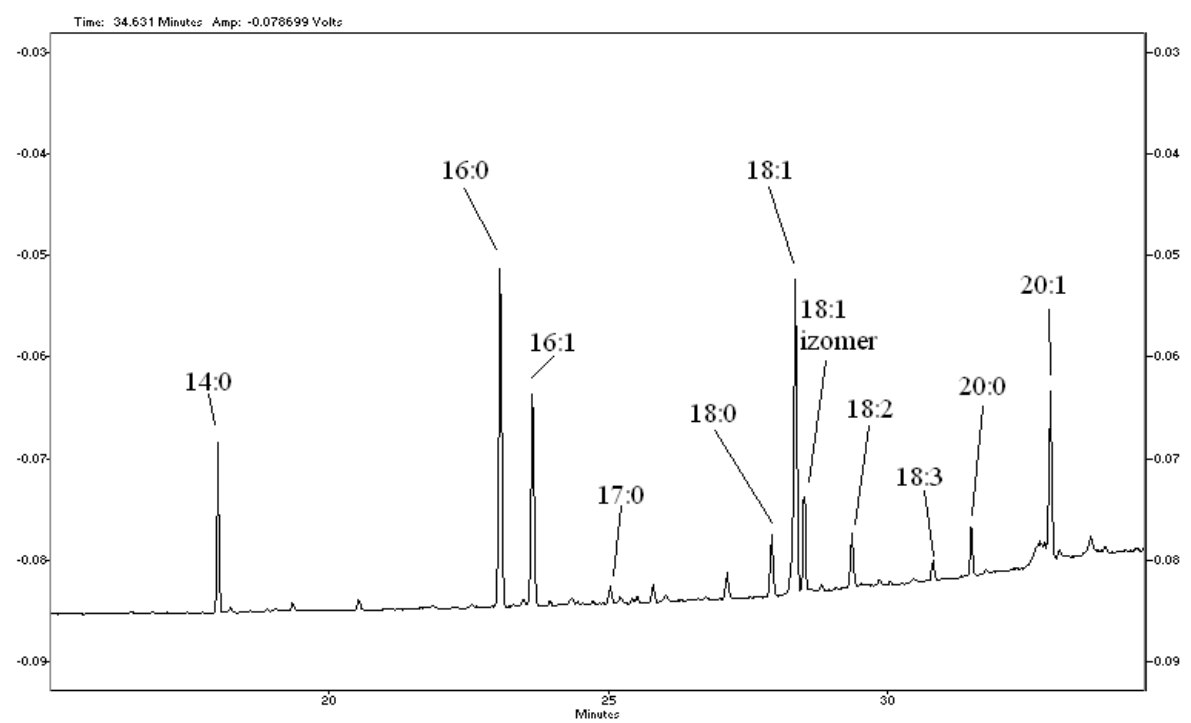

Figure 5. Gas chromatogram of $0.05 \%$ additivated fat at 180 days of storage 


\section{CONCLUSIONS}

Lipid oxidation in chicken fat varied with the duration of storage, type and concentration of antioxidant.

Peroxide value was significantly influenced by the storage time $(p<$ 0.001 ) in chicken fat and $0.01 \%$ additivated fat. Chicken fat without antioxidants was more unstable at storage, producing higher amounts of hydroperoxides.

Positive correlations between refractive index value and iodine value were found in control, $0.01 \% \beta$-carotene additivated fat, and $0.01 \%$ ascorbic acid additivated fat. Regardless of the type of fat, the lowest iodine index level was found at 180 days of storage.

Storage time inflicted changes in fatty acids profile, the most affected fraction was the polyunsaturated fatty acids, directly related with their higher number of double bonds, with higher susceptibility to oxidation.

The addition of $\beta$-carotene and ascorbic acid in proportion of $0.01 \%$ extended the shelf life of chicken fat stored at $2-4^{\circ} \mathrm{C}$ by 30 days, and antioxidants addition in proportion of $0.05 \%$ extended the shelf life by 60 days. Statistical analysis of the data revealed that the development of rancidity in chicken fat was significantly $(p<0.01)$ reduced by the addition of $\beta$-carotene and ascorbic acid in concentration of $0.05 \%$.

\section{EXPERIMENTAL SECTION}

\section{Samples}

The research was conducted on alimentary chicken fat and after the addition of antioxidants. Raw material was collected immediately after its obtaining from the slaughtered birds and consisted in abdominal fat out off the carcass. An average weight of $500 \mathrm{~g}$ of abdominal fat was cut into small pieces, heated at $65-75^{\circ} \mathrm{C}$, centrifuged, and filtered. $\beta$-Carotene and ascorbic acid were dissolved in the melted fat, each of them in two concentrations: $0.01(0.01 \mathrm{~g} / 100 \mathrm{~g}$ of fat) and $0.05 \%$ respectively $(0.05 \mathrm{~g} / 100 \mathrm{~g}$ of fat). The following treatments were investigated: (1) control (without antioxidant), (2) $\beta$-carotene $(0.01 \%)$, (3) $\beta$-carotene $(0.05 \%)$, (4) ascorbic acid $(0.01 \%)$, and (5) ascorbic acid (0.05\%).

In order to carry out fat analyses during storage for 180 days, more samples of $50 \mathrm{~g}$ from each treatment were packed in closed jars, stored under refrigeration $\left(2-4^{\circ} \mathrm{C}\right)$, and at 30 days intervals were used for chemical analysis. For evaluation of fat stability and monitoring the deterioration 
during storage, methods included peroxide value, acid value, refractive index value, iodine value and fatty acid composition. Three replications were carried out to examine each sample. All chemicals used were of analytical grade and obtained from Merck (Germany); $\beta$-carotene and ascorbic acid were purchased from Sigma (Sigma Chemicals, Shanghai, China).

\section{Physicochemical examination}

Peroxide value was determined using UV-VIS spectrophotometer. Thiocyanate ions $(\mathrm{SCN})$ react with $\mathrm{Fe}^{3+}$ ions to give a red-violet chromogen that can be determined spectrophotometrically, the absorbance of each solution was read at $500 \mathrm{~nm}$. To quantify PV, a calibration curve (absorbance at $500 \mathrm{~nm}$ vs. $\mathrm{Fe}^{3+}$ expressed in $\mu \mathrm{g}$ ) was constructed and peroxide value was expressed as meq $\mathrm{O}_{2} / \mathrm{kg}$ sample. lodine value was determined using Hanus method, was calculated as $\mathrm{g} \mathrm{I}_{2} / 100 \mathrm{~g}$ sample [23].

To determine the refractive index we used the PAL-RI (Tokyo, Japan) with the following technical characteristics: field: $1,3306-1,5284$; resolution: 0.0001; accuracy: \pm 0.0003 ; measuring temperature: $5-45^{\circ} \mathrm{C}$ (resolution $1^{\circ} \mathrm{C}$ ); measuring time: $3 \mathrm{~s}$; in accordance with the requirements of EMC Directive 93/68/EEC. Acid value determination consists in neutralizing acidity with sodium hydroxide $0.1 \mathrm{~N}$, using phenolphthaleine, as an indicator. Acidity was expressed as oleic acid grams to 100 grams sample [23].

Fatty acids composition was determined using a Shimadzu GC-17 A gas chromatograph (Tokyo, Japan) coupled with a flame ionization detector. The gas chromatography column is Altech AT-Wax, $(60 \mathrm{~m} \times 0.32 \mathrm{~mm} \times 0.5$ $\mu \mathrm{m})$, stationary phase (polyethylene); helium was used as a carrier gas at a pressure of $147 \mathrm{kPa}$, temperature of the injector and detector was set to $260^{\circ} \mathrm{C}$, and the oven program was the following: $70^{\circ} \mathrm{C}$ for 2 minutes, then the temperature was raised to $150^{\circ} \mathrm{C}$ with a gradient of $10^{\circ} \mathrm{C} /$ minute, a level of 3 minutes, and the temperature was raised to $235^{\circ} \mathrm{C}$ with a gradient of $4^{\circ} \mathrm{C} /$ minute. Identification and quantification of $\mathrm{FA}$ were performed by comparison with standards. Results were expressed as $\mathrm{g} / 100 \mathrm{~g}$ fat [24].

\section{Statistical analysis}

All analytical determinations were performed at least in triplicate. Values of different parameters were expressed as the mean \pm standard deviation $(X \pm S D)$. Tukey's honest significance test was carried out at a $95 \%$ confidence level $(p<0.05)$. The Pearson's correlation $(a=0.05)$ with two-tailed probability values was used to estimate the strength of association between chemical parameters. 


\section{ACKNOWLEDGMENT}

The results presented in this paper were obtained in the framework of the GNaC 2018 ARUT grant "Increasing the Chemical Stability of Animal Fats Rich in Unsaturated Fatty Acids by Antioxidants Addition", research Contract no. 3015/2019, with the financial support of the Technical University of Cluj-Napoca.

\section{REFERENCES}

1. C.A. Costa, A.S. Carlos, G.P. Gonzalez, R.P. Reis, European Journal of Nutrition, 2012, 51, 191.

2. F. Shahidi, in: Natural Antioxidants. Chemistry, Health Effects, and Applications. Ed. AOCS Press, Champaign, Illinois (USA), 1997, 11.

3. E.N. Frankel, Food Chemistry, 1996, 57, 51.

4. R.A. Riemersma, European Journal of Lipid Science and Technology, 2002, $104,419$.

5. B. Sultana, F. Anwar, R. Przybylski, Food Chemistry, 2007, 104, 997.

6. R. Kim, F. Labella, Journal of Lipid Research, 2010, 28, 1110.

7. E.N. Frankel, Progress in Lipid Research, 1998, 19, 24.

8. N.V. Yanishlieva, K. Aitzetmüller, V.G. Raneva, Fett/Lipid, 1998, 10, 444.

9. O. Roman, B. Heyd, B. Broyart, R. Castillo, M. N. Maillard, LWT - Food Science and Technology, 2013, 52, 49.

10. B. Roszkowska, M. Tanska, S. Czaplicki, I. Konopka, European Journal of Lipid Science and Technology, 2015, 117, 673.

11. E. Choe, D.B. Min, Comprehensive Reviews in Food Science and Food Safety, 2006, 5, 169.

12. S. Azadmard-Damirchi, F. Habibi-Nodeh, J. Hesari, M. Nemati, B.F. Achachloei, Food Chemistry, 2014, 121, 1211.

13. A. Kamal-Eldin, European Journal of Lipid Science and Technology, 2006, 58, 1051.

14. D.A. Pereira de Abreu, K.V. Rodriguez, J.M. Cruz Freire, Food Chemistry, 2006, 113, 1395.

15. K.H. Wagner, F. Wotruba, I. Elmadfa, European Journal of Lipid Science and Technology, 2011,103, 746.

16. S. Schmidt, J. Pokorny, Czech Journal of Food Science, 2015, 23, 93.

17. F. Caponio, A. Pasqualone, T. Gomes, European Food Research and Technology, 2014, 215, 114.

18. R.M. El-Abassy, P. Donfack, A. Materny, Food Research International, 2010, $43,694$. 
FLAVIA POP, DANIEL NĂSUI, ZORICA VOȘGAN, CRISTINA MIHALI, CLAUDIA BUTEAN

19. N. Rodrigues, R. Malheiro, S. Casal, M.C. Manzanera, Food and Chemical Toxicology, 2012, 50, 2894.

20. S. Ozturk, S. Cakmakci, European Journal of Lipid Science and Technology, 2006, 108, 951.

21. P.C. Zuta, B.K. Simpson, X. Zhao, L. Leclerc, Food Chemistry, 2007, 100, 800.

22. J. Jankowski, Z. Zdunczyk, D. Mikulski, J. Pomianowski, P. Zdunczyk, European Journal of Lipid Science and Technology, 2012, 114, 1025.

23. F. Pop, L. Mihalescu, International Journal of Food Properties, 2017, 20 , 1085.

24. F. Pop, Studia Universitatis Babes-Bolyai Chemia, 2018, 63, 43. 